\title{
3 Crop Production in Ethiopia: Regional Patterns and Trends
}

\author{
ALEMAYEHU SEYOUM TAFFESSE, PAUL DOROSH, \\ AND SINAFIKEH ASRAT GEMESSA
}

Ethiopia's crop agriculture is complex, involving substantial variation in crops grown across the country's different regions and ecologies. Five major cereals (teff, wheat, maize, sorghum, and barley) are the core of Ethiopia's agriculture and food economy, accounting for about three-fourths of the total area cultivated, 29 percent of agricultural gross domestic product (GDP) in 2005/06 (14 percent of total GDP), and 64 percent of calories consumed (FAO various years). There has been substantial growth in cereals in terms of area cultivated, yields, and production since 2000, but yields are low by international standards, and overall production is highly susceptible to weather shocks, particularly droughts. Thus, raising production levels and reducing their variability are essential aspects of improving food security in Ethiopia, both to help ensure adequate food availability and to increase rural household incomes.

Ethiopia's crop agriculture in general, and the cereals subsector in particular, face serious challenges. We show in this chapter that, although a majority of production increases in the past occurred due to increases in the area cultivated, recent data on production (from 2000/01-2008/09) suggest that yield increases and intensification may be contributing to greater production. Given that little suitable uncultivated land remains in the highlands apart from pasture land, production gains in terms of yield increases are critical to meet agricultural growth goals. Sustaining increased yields in the productive areas of the highlands is fraught with challenges, however. Soil degradation from erosion and soil compaction threatens crop yields (Taddesse 2001; Hamza and Anderson 2005). Furthermore, uncertain rainfall and very low levels of irrigation make intensive cultivation with improved seeds and fertilizer financially risky (McCann 1995).

This chapter presents an overview of crop agriculture, focusing mainly on cereal production. The next section describes the area and production levels of the main agricultural crops, distribution of cultivated area by farm size, and the importance of seasonal differentiation. The following section presents data on growth and variability of area, yield, and production of cereals in general, as well as for each major cereal crop separately. The results of a decomposition 
analysis of cereal production changes are discussed then. An overview of the production of other major agricultural crops, including enset, oilseeds, pulses, and export crops (coffee and chat) is presented next. The following section covers major constraints to increasing agricultural production, providing some international productivity data to compare with Ethiopia's agricultural productivity. The final section summarizes the chapter and presents concluding observations.

\section{Overview of Agricultural Crop Area and Production}

\section{Importance of Crop Categories}

Cultivated crop area (13 million hectares in 2007/08) accounts for a relatively small share (about 13 percent) of the total area of Ethiopia, because most land is not suited for cultivation. Table 3.1 shows the average area and production levels of the main crops cultivated for the period 2004/05-2007/08. Cereals dominate Ethiopian crop production. Cereals were grown on 73.4 percent of the total area cultivated by a total of 11.2 million farmers. Together, these holders produce a yearly average of 12 million tons of cereals. Teff accounts for 28 percent of the total cereal area cultivated, while maize comprises 27 percent of total annual cereal production, but only 19 percent of cereal area cultivated.

After cereals, the second most important crop group (in terms of acreage) is pulses. In 2004/05-2007/08, 6.4 million holders grew pulses on 12.4 percent of the total area cultivated. Total pulse production averaged 1.5 million tons per year. Oilseeds form the third most important crop group. In 2004/05-2007/08, they were cultivated on 6.9 percent of the total area cultivated by 3.1 million holders who produced an average of 0.5 million tons of oilseeds yearly. Coffee is a major cash crop, accounting for 3.8 percent of GDP (and 19 and 35 percent of the quantity and value of exports, respectively, in the period) but occupied only 2.7 percent of total area cultivated (that is, 306,000 hectares). Chat, another stimulant crop, was cultivated by 2 million farmers on 1.3 percent of the total area cultivated, and it accounted for 5 percent of total export earnings. Vegetables and root crops together were cultivated on 281,000 hectares comprising 2.6 percent of the total area cultivated.

\section{Distribution of Cultivated Land by Farm Size}

The Central Statistical Agency (CSA) classifies Ethiopian farms into two major groups: smallholder "peasant" farms and large commercial farms. Smallholders and larger farms are defined as those that cultivate less and more than 25.2 hectares, respectively. The majority of farmers in Ethiopia are smallholders. Their farms are often fragmented, produce mostly for the farmers' own consumption, and generate only a small marketed surplus. Large farms (averaging 323 hectares per farm) are state or private property, and they sell agricultural products at local markets or abroad. These larger farms typically use more 
TABLE 3.1 Crop area and production (smallholder farms, meher season), 2004/05-2007/08

\begin{tabular}{|c|c|c|c|c|}
\hline \multirow[b]{3}{*}{ Crop } & \multicolumn{4}{|c|}{ Average } \\
\hline & \multirow[b]{2}{*}{$\begin{array}{c}\text { Number } \\
\text { of holders } \\
\text { (thousands) }\end{array}$} & \multicolumn{2}{|c|}{ Area cultivated } & \multirow{2}{*}{$\begin{array}{c}\text { Production } \\
\text { Level } \\
\text { (thousands } \\
\text { of tons) }\end{array}$} \\
\hline & & $\begin{array}{l}\text { Level } \\
\text { (thousands } \\
\text { of hectares) }\end{array}$ & $\begin{array}{l}\text { Share in total } \\
\text { area cultivated } \\
\text { (percent) }\end{array}$ & \\
\hline Grain & 11,519 & 10,382 & 92.7 & 14,090 \\
\hline Cereals & 11,156 & 8,230 & 73.4 & 12,063 \\
\hline Teff & 5,462 & 2,337 & 20.9 & 2,408 \\
\hline Barley & 3,842 & 1,024 & 9.1 & 1,326 \\
\hline Wheat & 4,118 & 1,439 & 12.8 & 2,293 \\
\hline Maize & 7,287 & 1,595 & 14.2 & 3,314 \\
\hline Sorghum & 4,253 & 1,429 & 12.8 & 2,216 \\
\hline Pulses & 6,377 & 1,384 & 12.4 & 1,496 \\
\hline Oilseeds & 3,127 & 767 & 6.9 & 532 \\
\hline Vegetables & 4,936 & 106 & 1.0 & 425 \\
\hline Root crops & 4,757 & 174 & 1.6 & 1,473 \\
\hline Fruit crops & 2,658 & 51 & 0.5 & 403 \\
\hline Chat & 2,068 & 141 & 1.3 & 126 \\
\hline Coffee & 3,049 & 305 & 2.7 & 211 \\
\hline Hops & 1,685 & 23 & 0.2 & 26 \\
\hline Total & 30,675 & 11,186 & 100.0 & 16,755 \\
\hline
\end{tabular}

SOURCE: Authors' computations using data from Ethiopia, CSA (2006, 2008a, 2008b).

NOTE: CSA defines a holder as "a person who exercises management control over the operation of the agricultural holding and makes the major decision regarding the utilization of the available resources. He/she has primary technical and economic responsibility for the holding. He/she may operate the holding directly as an owner or a manager. Under conditions of traditional agricultural holding the holder may be regarded as the person, who with or without the help of others, operates land and/or raises livestock in his/her own right, that is the person who decides on which, where, when, and how to grow crops or raise livestock or both and has the right to determine the utilization of the products" (Ethiopia, CSA 2008b).

modern farm management practices and inputs (for example, machinery, irrigation, fertilizers, pesticides, and improved seeds) than do smaller farms. Large farms are not widespread in Ethiopia, and the contribution of these farms to total agricultural output is limited. It is estimated that large farms make up less than 4 percent of total production in the country (Ethiopia, CSA 2009). A recent study, however, suggests that international investors are making large-scale acquisitions of farmland in lowland areas of Ethiopia. Of the approved documented projects, it is estimated that approximately 603,000 hectares are under contract, with government leases for up to 50 years (Cotula et al. 2009). Although foreign direct investment in land is still small, substantial further investment 
could change the agricultural landscape as farms associated with it begin production and as future partnerships develop.

Table 3.2 shows area cultivated by farm size for the smallholder farms only. Each farm-size interval includes 20 percent of Ethiopia's smallholder farms. Sixty percent of smallholders in Ethiopia cultivate less than 0.90 hectare of land. Forty percent of the farmers cultivate less than 0.52 hectare, accounting for only 11 percent of the total area cultivated. On the other hand, medium-size farms, defined as those cultivating $0.90-25.2$ hectares, account for 75 percent of the total land cultivated.

Agricultural production varies widely across Ethiopia's agroecological regions, which are: moisture-reliable cereal areas, moisture-reliable enset areas, humid lowlands, drought-prone highlands, and pastoralist areas (see Chapter 2 and Table 3.2). Most smallholder farms are located in the moisture-reliable cereal-based highlands, which accounts for 59 percent of all farm area (that is, 48 percent cultivated by medium-sized farmers and 11 percent by small farmers [Figure 3.1]). The farm area in the drought-prone highlands represents 27 percent of the total area cultivated (that is, 20 percent on medium-sized farms and 7 percent on small farms).

TABLE 3.2 Total area cultivated, by farm size and agroecology, 2007/08

\begin{tabular}{lrrrrrr}
\hline \multicolumn{5}{c}{ Area cultivated (thousands of hectares) } \\
Farm size & $\begin{array}{c}\text { Moisture- } \\
\text { reliable } \\
\text { (hectares) }\end{array}$ & $\begin{array}{c}\text { Moisture- } \\
\text { celiable } \\
\text { censet }\end{array}$ & $\begin{array}{c}\text { Humid } \\
\text { lowland }\end{array}$ & $\begin{array}{c}\text { Drought- } \\
\text { prone }\end{array}$ & Pastoralist & Total \\
\hline $0.0-0.25$ & 111.7 & 133.2 & 6.5 & 76.9 & 6.8 & 335.1 \\
$0.25-0.52$ & 364.3 & 298.7 & 17.1 & 271.2 & 22.1 & 973.4 \\
$0.52-0.90$ & 884.0 & 355.7 & 31.0 & 474.3 & 39.4 & $1,784.4$ \\
$0.90-1.52$ & $1,739.5$ & 330.0 & 47.0 & 824.8 & 70.5 & $3,011.8$ \\
$1.52-25.20$ & $4,153.2$ & 272.4 & 94.4 & $1,617.8$ & 140.3 & $6,278.1$ \\
Total & $7,252.7$ & $1,390.0$ & 196.0 & $3,265.0$ & 279.1 & $12,382.8$ \\
& & Area cultivated (percentage of national total) & \\
$0.0-0.25$ & 0.9 & 1.1 & 0.1 & 0.6 & 0.1 & 2.7 \\
$0.25-0.52$ & 2.9 & 2.4 & 0.1 & 2.2 & 0.2 & 7.9 \\
$0.52-0.90$ & 7.1 & 2.9 & 0.3 & 3.8 & 0.3 & 14.4 \\
$0.90-1.52$ & 14.0 & 2.7 & 0.4 & 6.7 & 0.6 & 24.3 \\
$1.52-25.20$ & 33.5 & 2.2 & 0.8 & 13.1 & 1.1 & 50.7 \\
Total & 58.6 & 11.2 & 1.6 & 26.4 & 2.3 & 100.0 \\
\hline
\end{tabular}

SOURCE: Authors' calculations using data from Ethiopia, CSA (2008a, 2008b, 2009).

NOTE: Each farm-size interval (quintile) contains 20 percent of Ethiopia's small farms, approximately 2.57 million farms. 
FIGURE 3.1 Shares of area cultivated, by farm size and agroecology, 2007/08

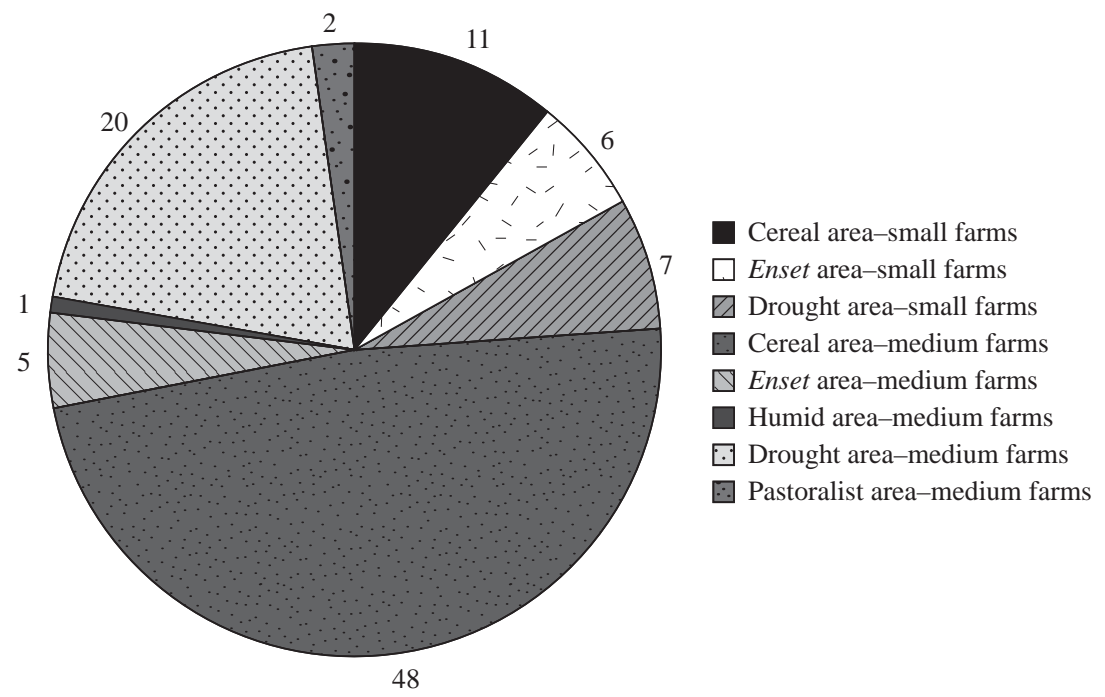

SOURCE: Ethiopia, CSA (2008a, 2008b, 2009).

NOTE: Small farms $=$ farms with a size of less than 0.90 hectare ( 60 percent of all farms); medium farms $=$ farms with a size of 0.90 or more hectares $(40$ percent of all farms).

Along with elevation and soil characteristics, reliable access to water is also an important determinant of agricultural productivity and incomes. However, in the moisture-reliable enset-based highlands (11 percent of total farm area, of which 5 percent are medium-sized and 6 percent are small farms), population pressure has diminished farm size to such an extent that outmigration has become a major pathway out of poverty. The farmers in the remaining two areas (humid lowlands and pastoralist areas) are relatively less important, accounting for only 3.9 percent of all smallholders in Ethiopia. ${ }^{1}$

\section{Crop Area and Production by Farm Size}

Tables 3.3 and 3.4 show the level of crop area and crop production by farm size for the year 2007/08 (Ethiopia, CSA 2008a, 2008b, 2009). That year, smallholder farmers (12.8 million farmers) cultivated a total of 13.0 million hectares of land (11.9 million hectares in the meher season and 1.1 million hectares in the belg season) or 96.6 percent of the total area cultivated. A total of 461,000 hectares was cultivated by large commercial farms. Smallholder farms generated 95 percent of the total production of the main crops (cereals, pulses, oil-

1. For an alternate estimate of the agropastoralist population in Ethiopia, see the Livelihoods Integration Unit database information in Chapter 7. 


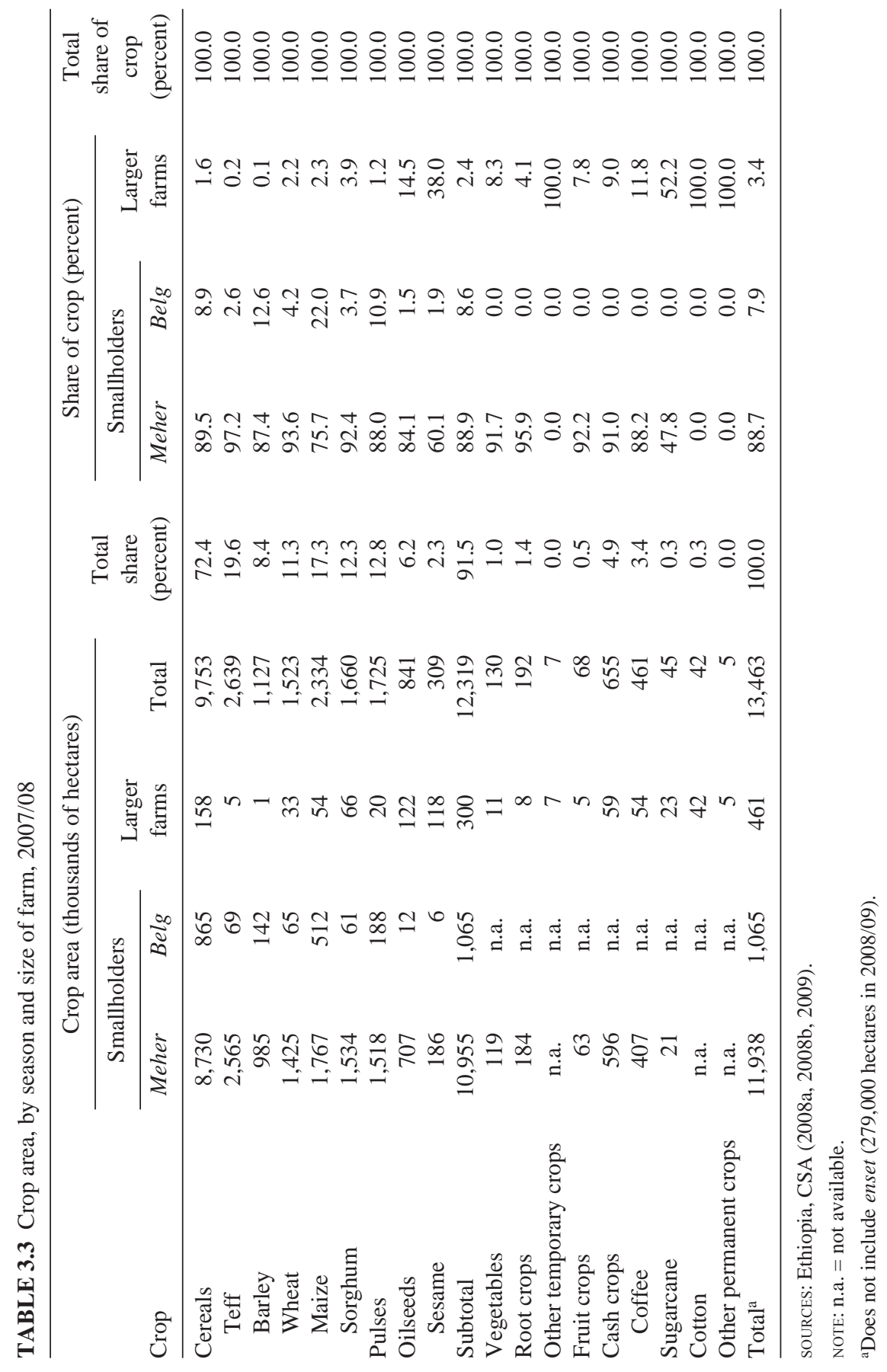




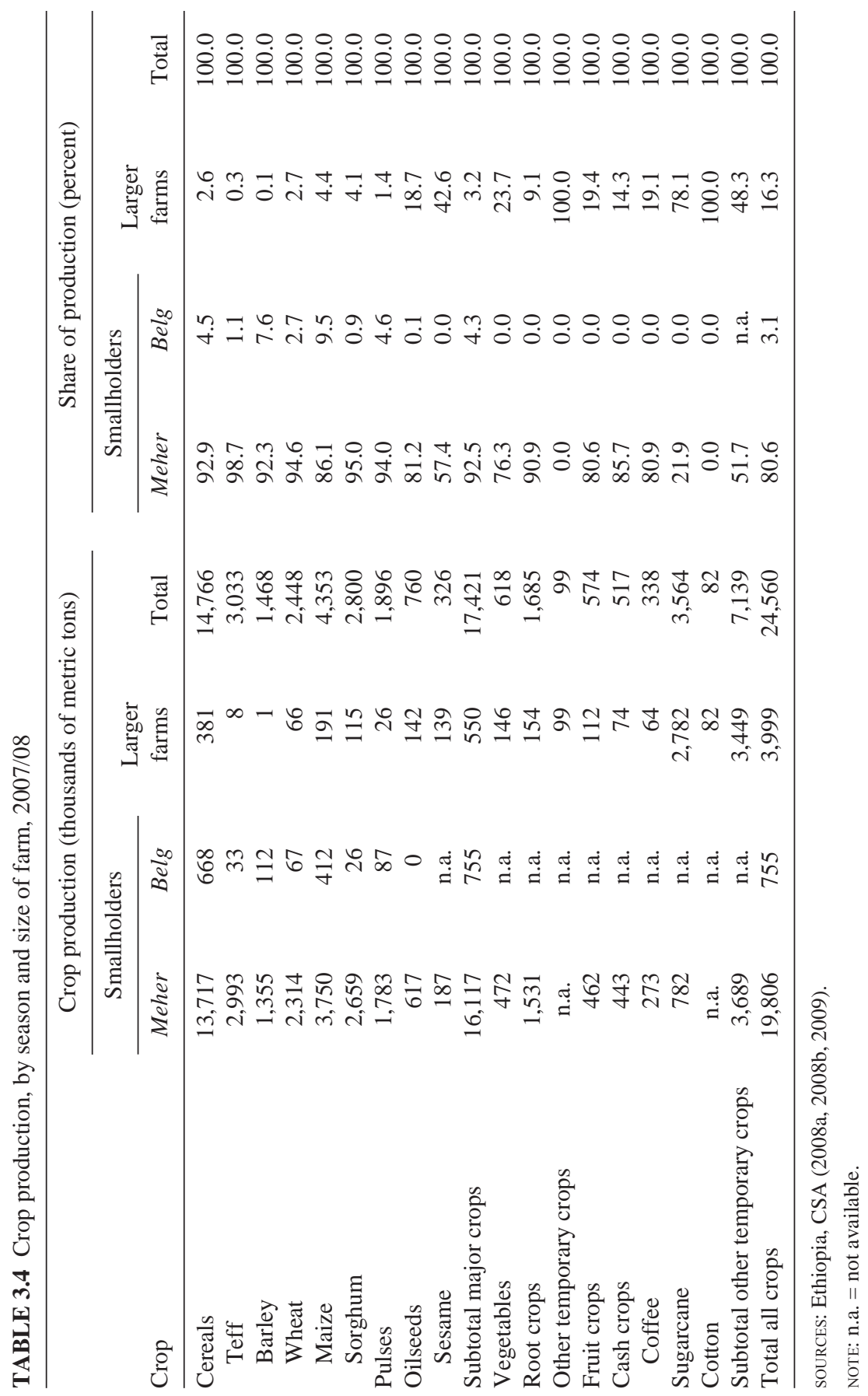


seeds, vegetables, root crops, fruits, and cash crops). In contrast, large farms contributed only 5 percent of total production of these main crops and only 2.6 percent of cereal production.

However, large farms accounted for a much larger share of the coffee (19.1 percent), fruit (19.4 percent), and vegetable (23.7 percent) production. Even higher shares were reported for sesame and sugarcane: 42.6 percent and 78.1 percent, respectively, of total production were grown on large farms. Similarly, cotton was produced only on large farms.

Because yields are usually higher on large farms, their share of production is often higher than their share of acreage. For example, sugarcane cultivated on large farms accounted for 52.2 percent of total sugarcane acreage, though it accounted for 78.1 percent of total sugarcane production. The yields were three times as high on large farms (119 tons per hectare), as on small farms (36 tons per hectare) (Table 3.5). Other large differences between area and production shares, driven by significant yield gaps, are seen for coffee (large farms: 11.8 percent of total coffee acreage, 19.1 percent of total coffee production) and

TABLE 3.5 Crop yields, by season and size of farm, 2007/08

\begin{tabular}{lccccc}
\hline & \multicolumn{3}{c}{ Crop yield (metric tons per hectare) } & & $\begin{array}{c}\text { Yield } \\
\text { proportion } \\
\text { Crop }\end{array}$ \\
\cline { 2 - 5 } & $\begin{array}{c}\text { Smallholders, } \\
\text { meher }\end{array}$ & $\begin{array}{c}\text { Smallholders, } \\
\text { belg }\end{array}$ & $\begin{array}{c}\text { Larger farms, } \\
\text { meher }\end{array}$ & $\begin{array}{c}\text { Yield } \\
\text { total }\end{array}$ & $\begin{array}{c}\text { meher, } \\
\text { large/small }\end{array}$ \\
\hline Cereals & 1.57 & 0.77 & 2.41 & 1.51 & 1.53 \\
Teff & 1.17 & 0.47 & 1.66 & 1.15 & 1.43 \\
Barley & 1.38 & 0.79 & 1.87 & 1.30 & 1.36 \\
Wheat & 1.62 & 1.04 & 1.97 & 1.61 & 1.22 \\
Maize & 2.12 & 0.80 & 3.55 & 1.87 & 1.67 \\
Sorghum & 1.73 & 0.42 & 1.76 & 1.69 & 1.01 \\
Pulses & 1.17 & 0.46 & 1.29 & 1.10 & 1.10 \\
Oilseeds & 0.87 & 0.04 & 1.17 & 0.90 & 1.34 \\
$\quad$ Sesame & 1.00 & n.a. & 1.18 & 1.05 & 1.17 \\
Subtotal & 1.47 & 0.71 & 1.83 & 1.41 & 1.25 \\
Vegetables & 3.96 & n.a. & 13.49 & 4.76 & 3.40 \\
Root crops & 8.31 & n.a. & 19.66 & 8.77 & 2.37 \\
Other temporary crops & n.a. & n.a. & 15.14 & 15.14 & n.a. \\
Fruit crops & 7.37 & n.a. & 20.90 & 8.43 & 2.84 \\
Cash crops & 0.74 & n.a. & 1.26 & 0.79 & 1.69 \\
$\quad$ Coffee & 0.67 & n.a. & 1.19 & 0.73 & 1.77 \\
Sugarcane & 36.39 & n.a. & 118.57 & 79.29 & 3.26 \\
Cotton & n.a. & n.a. & 1.96 & 1.96 & n.a. \\
\hline
\end{tabular}

SOURCES: Ethiopia, CSA (2008a, 2008b, 2009).

NOTE: n.a. = not available. 
maize (large farms: 2.3 percent of total maize acreage, 4.4 percent of total maize production).

\section{Seasonal Variation}

In the main agricultural regions of Ethiopia, there are two rainy seasons, the meher and the belg seasons, and consequently there are two crop seasons. The meher season is the main production season. It encompasses crops harvested between Meskerem (September) and Yekatit (February). Crops harvested between Megabit (March) and Nehase (August) are considered part of the belg-season crop. Tables 3.3, 3.4, and 3.5 present data on crop area, production, and yield by season for 2007/08 (CSA data). There are three important insights from these tables. First, only smallholder farmers cultivate crops during the belg season, as large farms concentrate their production entirely on the more productive meher season. Second, the meher season is overwhelmingly important. The area cultivated and crop production in the meher season account for 92.1 percent of the total area cultivated and 96.9 percent of the total crop production. Third, crop yields are usually smaller in the belg season than in the meher season.

Smallholder cereal production in the meher season dominates cereal production in Ethiopia and accounted for 93 percent of national cereal production in 2007/08. Although 8.9 percent of the total cereal area was cultivated during the belg season, only 4.5 percent of national cereal production was produced in the belg season, a reflection of the significantly lower yields in this season. The most important contribution of the belg season to total production is maize: 22.0 percent of the total maize area was cultivated in the belg season, producing 9.5 percent of total maize output.

\section{Cereal Production Trends}

\section{Trends in Total Cereal Production}

Data on national cereal production levels and trends are controversial. Changes in government and methodologies have coincided with distinct breaks in the data, making it difficult to distinguish between actual changes and statistical artifacts. Moreover, beginning in 1981/82, there have been two alternative data sources for each year, one from the Ministry of Agriculture and Rural Development (or its predecessors) and one from the CSA. We present the descriptive statistics of agricultural production and areas in Table 3.1.

Data from the Food and Agricultural Organization (FAO), generally derived from the Ministry of Agriculture and Rural Development or its predecessors, indicate a steady but slow 1.9 percent average growth in cereal production in the 1960 s, due almost equally to modest area (1.1 percent per year) and 
yield (0.8 percent per year) increases (Table 3.6). Given a population growth rate estimated at 2.3 percent per year in this period, it is estimated that per capita production declined by an average of 0.4 percent per year. Due to the poor state of infrastructure and weak statistical capacity in the country in the 1960s, the degree of uncertainty in this data is rather high, however.

Cereal production showed high variability at the beginning of the 1970s. Cereal production decreased from 5.17 million tons in 1972/73 to 4.37 and 4.35 million tons in 1973/74 and 1974/75, respectively, before falling even more dramatically, to only 3.81 million tons in 1975/76, that is, 31 percent below the production in 1972/73. Food aid and other net imports of cereals increased more than 10 -fold between $1972 / 73$ and $1974 / 75$, from 8,000 to 112,000 tons, but they were nonetheless far too small to offset the decline in production. As a result, per capita availability of food fell from 138 kilograms per person per year in 1972/73 to only 113 kilograms per person per year in 1973/74 and $1974 / 75$, then plummeted to only 96 kilograms per person per year in 1975/76 (Figure 3.2). ${ }^{2}$

The major cause of the reported production fall between 1972/73 and 1975/76 was a steep 31 percent decrease in the cultivated area of cereals, a decline equal to the decline in production. Two factors may have contributed to the change in cultivated area in that period: the revolution of 1973 (that is, the fall of the imperial regime of Haile Selassie) and the subsequent land reform and the regulation of cereal prices beginning in 1975, which may have reduced incentives for production (or even led to major incentives to underreport production). In addition, parts of Ethiopia experienced major droughts during this time, which contributed to famine conditions. The meher rains of 1972 and the belg rains of 1973 failed or were insignificant in large areas of the country, leading to what has been described by many as the 1972-74 famine, in which Wollo and parts of Tigray experienced repeated crop failures. According to Kloos and Lindtjorn (1993), by 1975 five regions were affected by the inadequate rains. Estimates suggest that cattle herds were reduced by 72 percent in Afar region during the 1972-74 famine (Devereux 2000). However, some of the decline in reported cultivated area may also have been due to differences in methodology and in the implementation of production surveys under the Derg regime.

2. The figure for availability of food includes an adjustment for postharvest production losses of about 5 percent, as well as feed, seed, and other nonfood uses. Data on the FAO Food Balance Sheets (FAO various years) show almost no decline in food availability per capita in this period (from 116.7 kilograms per person per year in 1972/73 to 113.3 kilograms per person per year in 1975/76) due to very large changes in stocks. From 1961/62 through 1972/73, stocks rose each year, with a cumulative buildup of 4.46 million tons. Thus, per capita food availability for these years was reduced accordingly. The FAO data then show a drawdown of stocks of 50,000 tons per year in 1973/74 and $1974 / 75$, followed by a drawdown of 650,000 tons in $1975 / 76$, which raised per capita food availability in these years (see Figure 3.2). 


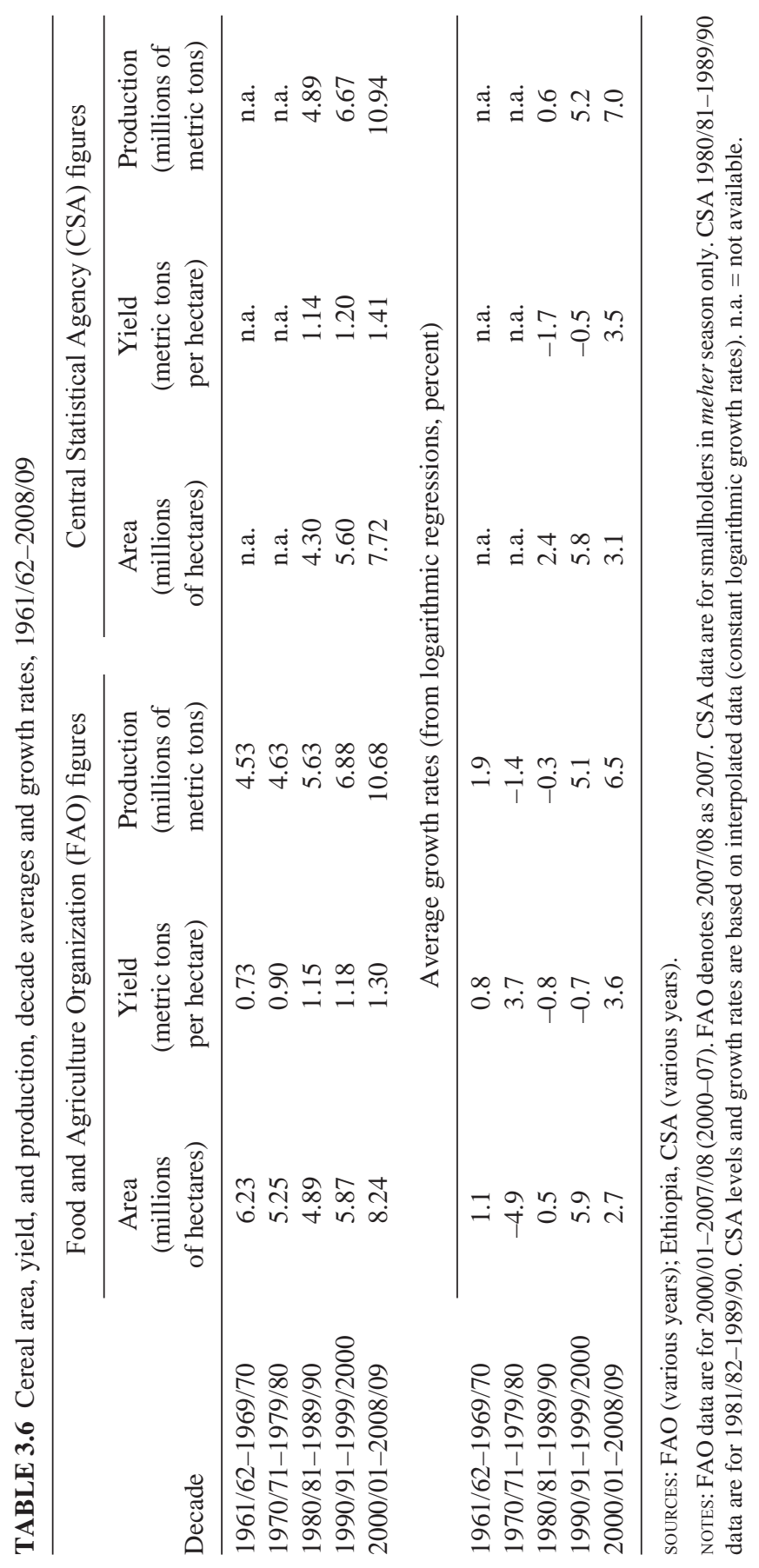


FIGURE 3.2 Per capita cereal consumption and imports, 1961/62-2008/09

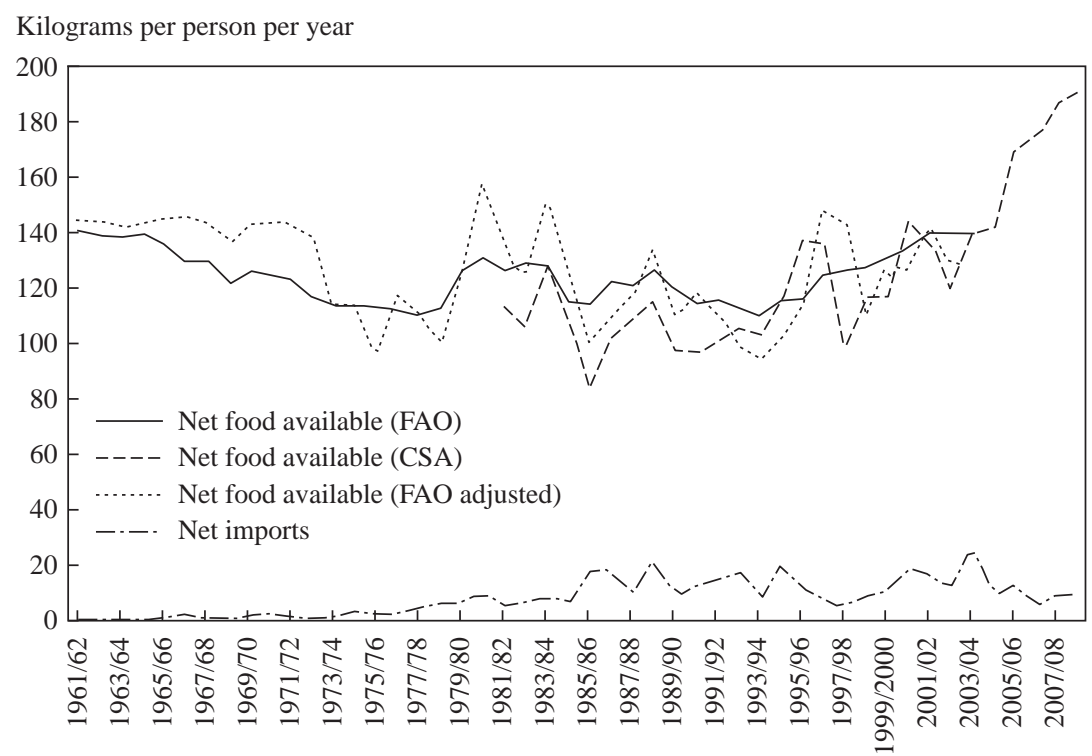

SOURCE: FAO (various years; Ethiopia, CSA (various years).

NOTE: CSA = Central Statistical Agency; FAO = Food and Agriculture Organization .

There were wide fluctuations in food production and net availability in the second half of the 1970s and the 1980s, but overall, cereal production stagnated in this period (see Figure 3.2 and Table 3.6). The average growth rate of production from $1979 / 80$ to $1989 / 90$ was -0.3 percent according to FAO data; CSA data for 1981/82-1989/90 indicate that the growth rate was 0.6 percent. In the 1990s, growth in cereal production accelerated to about 5 percent per year (according to both FAO and CSA data). The rise during the 1990s was entirely due to increases in the area cultivated (by almost 6 percent per year, as reflected in both the FAO and CSA data; see Table 3.6), while yields continued to decline by $0.5-0.7$ percent per year. A shift then occurred in the 2000 s, whereby the growth in area cultivated was reduced to nearly half of the growth rate experienced during the 1990s, while yield growth became positive and increased three-fold.

According to CSA data, growth in cereal production further accelerated to 7.0 percent per year from $1999 / 2000$ to $2008 / 09$. Average cereal production increased to 10.94 million tons per year during this period. Though growth in the area cultivated slowed to 3.1 percent per year, yields increased by 3.5 percent per year. Cereal production and yield growth were particularly rapid from 2004/05 to 2008/09 (12.2 and 6.2 percent, respectively), while cereal acreage 
showed a slower annual growth rate of 4.8 percent (significantly lower than the previous growth in area expansion, but relatively high given the area constraints within productive areas in Ethiopia) (Table 3.7). During the same period, cereal production on average involved 11 million holders. Cereal acreage and cereal output averaged 8.2 million hectares and 12.1 million tons, respectively.

\section{Trends in the Production of the Major Cereals}

Since the collection of national agricultural statistics began in the 1960s, teff has always accounted for the largest share of cereal area cultivated (Table 3.8). However, over the past five decades the share of teff has declined gradually (a decrease of 5.8 percentage points from the 1960s to the first decade of the 2000s), while the share of maize has increased by 7.8 percentage points. Compared to teff and maize, the share of other cereals stayed relatively stable over time.

During the first decade of the 2000s, production of the major cereals increased, with teff ( 8.9 percent), sorghum ( 8.6 percent), and wheat ( 8.3 percent) having the fastest annual growth rates. Growth in maize production, at 6.8 percent per year in the 1980s and 5.5 percent per year in the 1990s, slowed to 4.2 percent in the early 2000s. This reduced growth figure was caused in part by a collapse in domestic maize prices, which induced slow adoption, or even disadoption, of hybrid maize technology.

Compared to the 1990s, the area cultivated in wheat and sorghum grew fastest (by 4.9 and 4.6 percent per year, respectively) during 2000/01-2008/09, while the area cultivated in maize increased by only 1.6 percent per year. Yields of all five major cereals increased rapidly in the first decade of the 2000s, with growth rates averaging between 2.9 and 3.0 percent per year for maize and wheat and between 4.3 and 4.8 percent per year for sorghum and teff. ${ }^{3}$

Because the total growth of cereal production was particularly rapid from $2004 / 05$ to $2008 / 09$, it is worth examining the growth rates of the five cereals separately in this period (see Table 3.7). The speed of growth was somewhat varied across crops. The average annual growth in output was fastest in maize production (18.9 percent), closely followed by sorghum production (18.3 percent). Teff production rose by 15.9 percent per year. The slowest output growth was recorded in barley production ( 0.7 percent) due to a decline in barley acreage. It is interesting to note that, for the main cereals, yield growth was faster than acreage expansion during the period, so the increased production rates were the result more of increased yields than of increased acreages. An excep-

3. At first glance it is surprising that sorghum and teff have had greater growth rates given that maize and wheat yields have been more responsive to the use of fertilizer and modern seeds (as discussed later in this chapter). However, expansion of modern input use proved insufficient as an explanation for the growth in yields recorded in the CSA data. Further discussion of this issue can be found in Asrat, Getachew, and Taffesse (2010). 


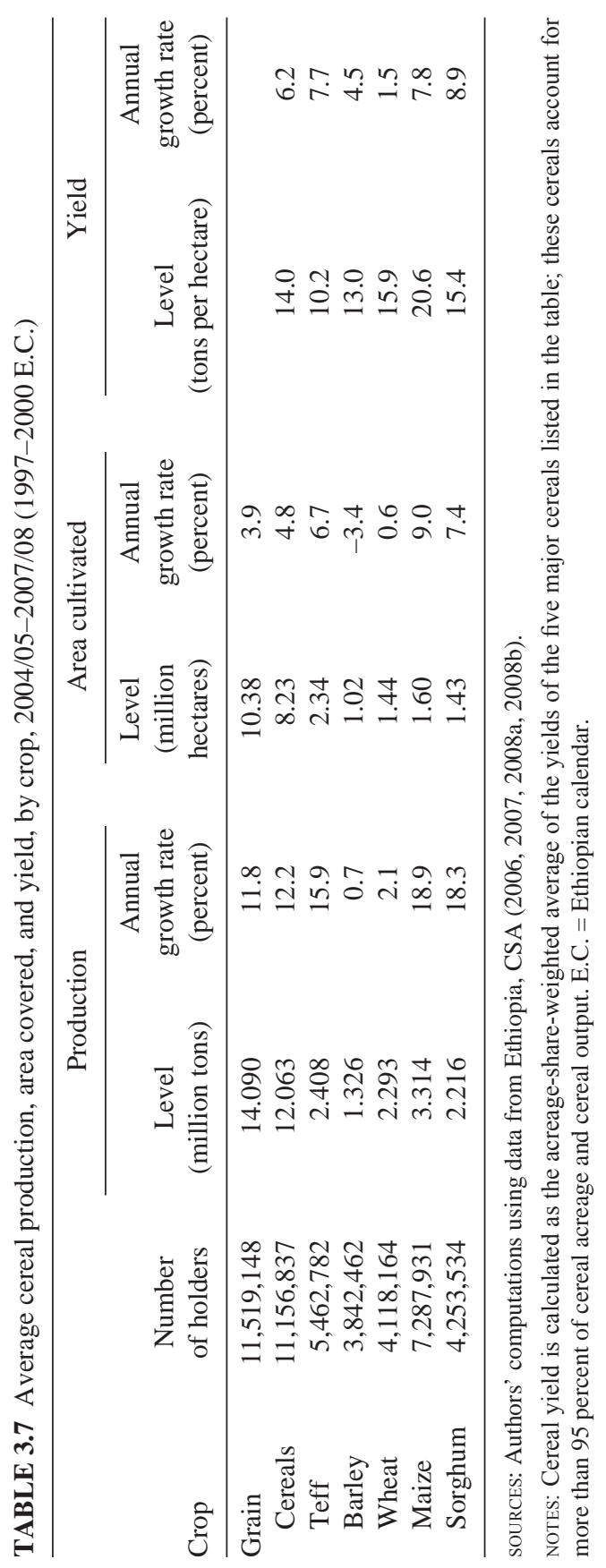


TABLE 3.8 Cereal area cultivated, decade averages, 1961/62-2008/09

\begin{tabular}{lccccccr}
\hline & \multicolumn{7}{c}{ Cereal and area cultivated (millions of hectares) } \\
\cline { 2 - 8 } Decade & Teff & Wheat & Maize & Sorghum & Barley & Other & Total \\
\hline 1961/62-1969/70 & 2.11 & 0.97 & 0.80 & 1.09 & 0.96 & 0.30 & 6.23 \\
1970/71-1979/80 & 1.67 & 0.78 & 0.83 & 0.87 & 0.84 & 0.27 & 5.25 \\
1980/81-1989/90 & 1.23 & 0.52 & 0.84 & 0.71 & 0.86 & 0.15 & 4.30 \\
$1990 / 91-1999 / 2000$ & 1.76 & 0.75 & 1.12 & 0.95 & 0.73 & 0.29 & 5.60 \\
2000/01-2008/09 & 2.17 & 1.27 & 1.59 & 1.35 & 0.96 & 0.38 & 7.72 \\
& & & & & & & \\
$1961 / 62-1969 / 70$ & 33.9 & 15.6 & 12.8 & 17.4 & 15.4 & 4.9 & 100.0 \\
$1970 / 71-1979 / 80$ & 31.8 & 14.8 & 15.7 & 16.6 & 15.9 & 5.1 & 100.0 \\
$1980 / 81-1989 / 90$ & 28.7 & 12.0 & 19.5 & 16.4 & 19.9 & 3.4 & 100.0 \\
$1990 / 91-1999 / 2000$ & 31.3 & 13.4 & 20.0 & 17.0 & 13.1 & 5.2 & 100.0 \\
2000/01-2008/09 & 28.1 & 16.5 & 20.6 & 17.5 & 12.5 & 4.9 & 100.0 \\
\hline
\end{tabular}

SOURCES: 1961/62-1979/80 data are from the Food and Agriculture Organization; 1980/81-2008/09 data are from Central Statistical Agency Agricultural Sample Surveys.

tion to this was maize, a crop considered to have the highest potential for yield increases. Over this four-year period, the yield of maize increased by 7.8 percent, while its area grew by 9 percent.

\section{Decomposition Analysis of Cereal Production}

\section{Methodology}

Agroecology and market infrastructure, the key components of the development domains, are important determinants of crop production and revenue. In this section we decompose changes in cereal output into changes in area and yield across various development domains and time periods. We also examine changes in gross crop revenues by total output and price.

The quantity of output of crop $i\left(Q_{t}^{i}\right)$ is the product of yield $\left(y_{t}^{i}\right)$ and acreage allocated to its production $\left(A_{t}^{i}\right)$. Decomposition can thus take the following approximate form:

$$
d Q_{i} \cong A_{i} d y_{i}+y_{i} d A_{i} .
$$

The decomposition reveals the relative contribution of changes in acreage and yield to the overall change in the quantity of output. This is a policy-relevant issue to the extent that acreage and, to a certain degree, yield reflect government interventions in agriculture and the wider economy and are not determined simply by variations in weather and the severity of pest attacks. 
A more informative decomposition involves crop revenues. Such a decomposition can highlight, in addition to the relative contributions of changes in acreage and yield as quantity decomposition, changes in prices and the pattern of allocation of acreage. Changes in prices reflect in part market development, while patterns of acreage allocation are partly driven by differences in returns to the cultivation of alternative crops. Both are relevant to policy decisions.

The total revenue from cereal cultivation $(R)$ is given by the sum of revenues from each cereal type $i$ :

$$
R=\sum_{i=1}^{n} p_{i} Q_{i}=\sum_{i=1}^{n} p_{i}\left(A_{i} y_{i}\right)
$$

where $p_{i}=$ price of cereal $i$ and the other variables are as defined earlier. Defining total cereal acreage as $A=\sum_{i=1}^{n} A_{i}$ and the share of each cereal in total acreage as $a_{i}=\frac{A_{i}}{A}$, cereal revenue can be computed as

$$
R=\sum_{i=1}^{n} p_{i}\left(a_{i} A y_{i}\right)=A\left(\sum_{i=1}^{n} p_{i} a_{i} y_{i}\right)
$$

The expression shows that there are four potential sources of growthchanges in total acreage, changes in the shares of crops in total acreage, changes in crop yields, and changes in crop prices. Thus, approximately

$$
d R \cong\left(\sum_{i=1}^{n} a_{i} y_{i} p_{i}\right) d A+A \sum_{i=1}^{n} a_{i} y_{i} d p_{i}+A \sum_{i=1}^{n} a_{i} p_{i} d y_{i}+\sum_{i=1}^{n} y_{i} p_{i} d a_{i}{ }^{4}
$$

The first term on the right hand side of the equation denotes the change in the gross crop income due to changes in total cropped area; the second term gives the effect of changes in real prices; the third term captures the effect of change in crop yields; and the fourth term describes the change in gross crop income associated with changes in the area composition of crops over time. If the fourth term is positive, this indicates a reallocation of cropland from lowervalue crops to higher-value crops, so this term represents the effect of crop diversification on gross crop income. Dividing both sides of the equation by the overall change in gross crop income $(d R)$ gives the proportional contribution of each component of the growth.

4. For a single crop, the expression reduces to

$$
d R_{i} \cong y_{i} p_{i} d A_{i}+y_{i} A d p_{i}+p_{i} A_{i} d y_{i} .
$$

A more detailed description of the decomposition approach and its application can be found in Taffesse (2009). 


\section{Decomposition of Changes in Total Cereal Revenue}

Tables 3.9 and 3.10 show the results of a decomposition of changes in cereal output and cereal revenue across various development domains for the four main administrative regions-Amhara, Oromiya, the Southern Nations, Nationalities, and People's Region, and Tigray. The data used in this analysis are derived from CSA Agricultural Sample Surveys at the administrative zone level for the period 1996/97-2007/08 (1989-2000 E.C. [Ethiopian calendar]). Four development domains are considered: low market access (LMA) with low agricultural potential (LAP), LMA with high agricultural potential (HAP), high market access (HMA) with LAP, and HMA with HAP.

For cereal production, the broad story is very clear (see Table 3.9). During the study period, acreage expansion was the more important source of growth in output for four of the five major cereals (the exception is teff) in almost all development domains. Out of the 60 crop-domain-period specific pairs of yield and acreage contribution shares, for only 12 was the share of yield higher. Moreover, no statistically significant correlation can be detected between the acreage share of a crop and yield changes as a source of growth in that crop's output. Likewise, the relative contributions of acreage and yield changes to output growth were not statistically significantly different across development domains or time periods, except in the case of sorghum (see Taffesse 2009). Similar findings were discussed in Chapter 2; development domain classification was not a strong indicator of yield increases, but good market access and high labor to land density were good indicators.

The average picture for the decomposition of cereal revenues across development domains is also relatively simple (Table 3.10). For all cereals, acreage expansion was the top source of revenue change. This is to be expected because acreage increase generated the bulk of output growth during the period. Increases in yield were the second-largest contributor to revenue growth in the cases of maize, sorghum, and wheat. Real price rises and acreage expansion were the top two sources of growth only for barley and teff revenue (in fact, price and acreage contributed equally to teff revenue growth).

This general picture holds across development domains and periods. As in the case of output change, it was not possible to detect statistically significant differences across development domains in the pattern of contributions to the growth of each crop's revenue (with the exception of teff). ${ }^{5}$ In contrast, differences across periods are statistically significant (with the exceptions of yield contributions to the growth in barley revenue, sorghum revenue, and wheat revenue). A closer look at these time differences revealed the following. During

5. Note that there are 5 significant differences (out of a possible 15), with levels of significance falling between 5 percent and 10 percent. These are yield contributions in the cases of sorghum, wheat, and teff and area and price contributions in the case of teff. 


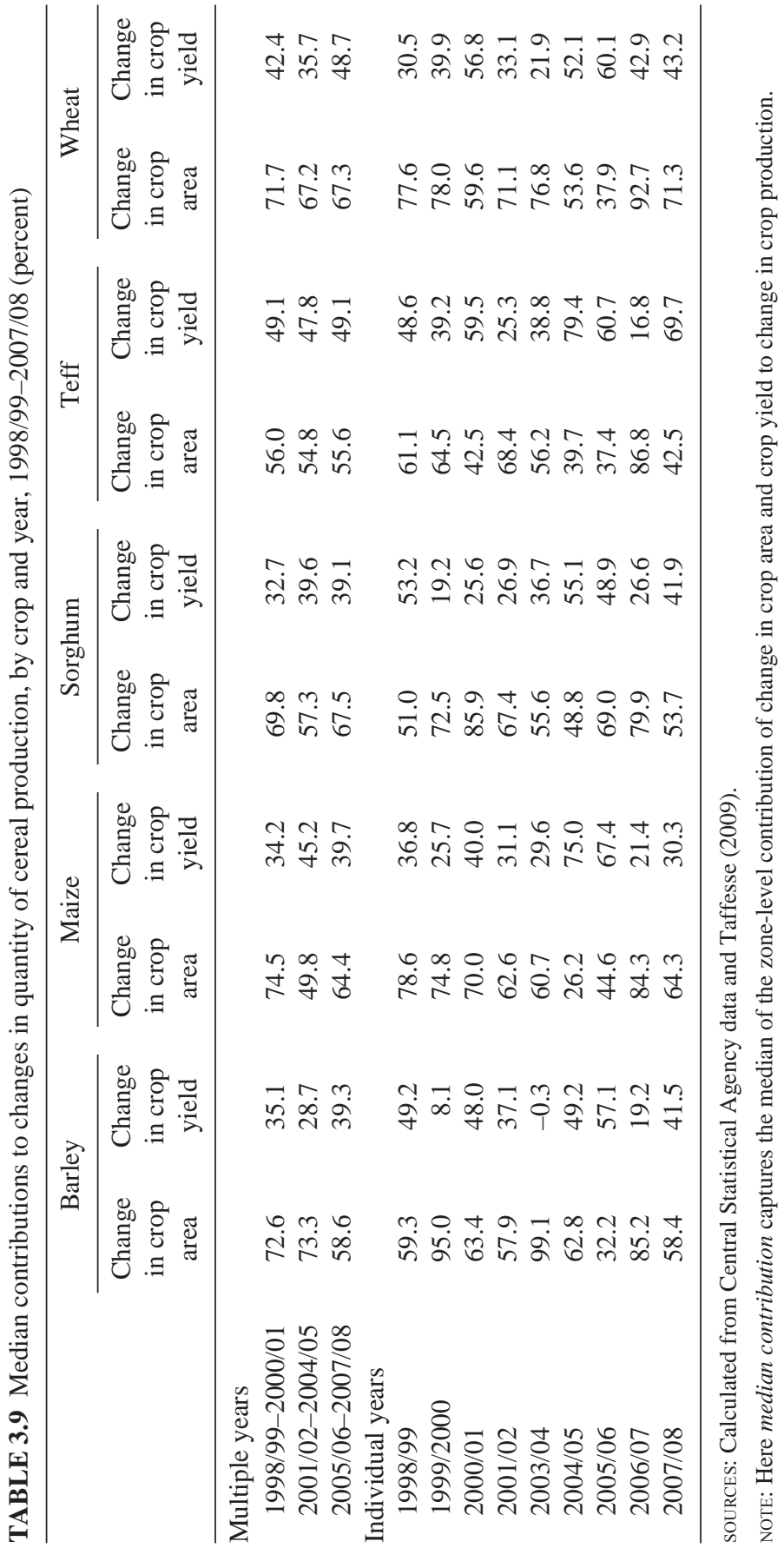


TABLE 3.10 Median contributions to changes in cereal revenue, by crop and development domain, all periods, 1998/99-2007/08 (percent)

\begin{tabular}{|c|c|c|c|c|c|}
\hline $\begin{array}{l}\text { Development } \\
\text { domain }\end{array}$ & Crop & $\begin{array}{l}\text { Change in } \\
\text { crop area }\end{array}$ & $\begin{array}{l}\text { Change in } \\
\text { crop yield }\end{array}$ & $\begin{array}{l}\text { Change in } \\
\text { crop price }\end{array}$ & $\begin{array}{c}\text { Actual } \\
\text { change minus } \\
\text { estimated change }\end{array}$ \\
\hline \multirow[t]{5}{*}{ LMA, LAP } & Barley & 54.6 & 14.7 & 20.5 & 10.2 \\
\hline & Maize & 47.2 & 14.1 & 24.9 & 13.9 \\
\hline & Sorghum & 30.6 & 29.9 & 26.7 & 12.8 \\
\hline & Teff & 51.8 & 25.2 & 15.7 & 7.3 \\
\hline & Wheat & 55.7 & 38.7 & 7.5 & -1.9 \\
\hline \multirow[t]{5}{*}{ LMA, HAP } & Barley & 38.4 & 13.1 & 37.6 & 10.9 \\
\hline & Maize & 51.7 & 35.0 & 17.1 & -3.9 \\
\hline & Sorghum & 48.0 & 14.6 & 15.2 & 22.2 \\
\hline & Teff & 38.4 & 9.3 & 73.8 & -21.5 \\
\hline & Wheat & 47.5 & 30.7 & 35.3 & -13.5 \\
\hline \multirow[t]{5}{*}{ HMA, LAP } & Barley & 54.6 & 21.3 & 28.5 & -4.4 \\
\hline & Maize & 41.8 & 50.7 & -3.9 & 11.5 \\
\hline & Sorghum & 42.4 & 33.0 & 28.6 & -4.0 \\
\hline & Teff & 27.7 & 29.4 & 42.1 & 0.8 \\
\hline & Wheat & 50.2 & 32.7 & 23.0 & -6.0 \\
\hline \multirow[t]{5}{*}{ HMA, HAP } & Barley & 53.7 & 17.2 & 25.4 & 3.7 \\
\hline & Maize & 53.5 & 15.6 & 13.5 & 17.4 \\
\hline & Sorghum & 60.5 & 19.4 & 11.3 & 8.7 \\
\hline & Teff & 41.8 & 21.0 & 27.9 & 9.3 \\
\hline & Wheat & 41.5 & 26.8 & 17.2 & 14.4 \\
\hline \multirow[t]{5}{*}{ Average } & Barley & 50.3 & 16.6 & 28 & 5.1 \\
\hline & Maize & 48.6 & 28.9 & 12.9 & 9.7 \\
\hline & Sorghum & 45.4 & 24.2 & 20.5 & 9.9 \\
\hline & Teff & 39.9 & 21.2 & 39.9 & -1.0 \\
\hline & Wheat & 48.7 & 32.2 & 20.8 & -1.8 \\
\hline
\end{tabular}

SOURCE: Authors' computations using Central Statistical Agency data (Ethiopia, CSA, various years). NOTE: HAP = high agricultural potential; HMA = high market access; LAP = low agricultural potential; LMA = low market access.

the first period (1998/99-2000/01), acreage expansion was the dominant source of change in cereal revenue, followed by yield (see Table 3.11). Price increases became the top contributor to revenue growth in the second period, with acreage change taking second place. Yield improvements played a limited role during this period. The third period was characterized by more mixed outcomes. Increases in acreage generated the largest contribution to revenue growth in the cases of barley, maize, sorghum, and teff, while yield change did so for wheat revenue. Crop prices also made significant contributions to revenue growth in this third period. 
TABLE 3.11 Median contributions to changes in cereal revenue, by crop and period, 1998/99-2007/08 (percent)

\begin{tabular}{|c|c|c|c|c|}
\hline \multirow[b]{2}{*}{ Crop revenue } & \multirow[b]{2}{*}{ Source of revenue growth } & \multicolumn{3}{|c|}{ Period } \\
\hline & & $\begin{array}{c}1998 / 99- \\
2000 / 01\end{array}$ & $\begin{array}{c}2001 / 02- \\
2004 / 05\end{array}$ & $\begin{array}{c}2005 / 06- \\
2007 / 08\end{array}$ \\
\hline \multirow[t]{3}{*}{ Barley revenue } & Change in crop area & 75.9 & 31.2 & 43.1 \\
\hline & Change in crop yield & 21.0 & 6.4 & 24.6 \\
\hline & Change in crop price & 7.9 & 55.7 & 36.0 \\
\hline \multirow[t]{3}{*}{ Maize revenue } & Change in crop area & 72.5 & 25.0 & 49.2 \\
\hline & Change in crop yield & 29.4 & 0.5 & 31.2 \\
\hline & Change in crop price & 6.4 & 53.1 & 13.2 \\
\hline \multirow[t]{3}{*}{ Sorghum revenue } & Change in crop area & 69.7 & 28.2 & 40.1 \\
\hline & Change in crop yield & 25.1 & 10.5 & 34.4 \\
\hline & Change in crop price & 5.8 & 41.3 & 25.3 \\
\hline \multirow[t]{3}{*}{ Teff revenue } & Change in crop area & 58.9 & 28.0 & 43.5 \\
\hline & Change in crop yield & 42.9 & 5.7 & 21.4 \\
\hline & Change in crop price & 14.0 & 47.7 & 37.0 \\
\hline \multirow[t]{3}{*}{ Wheat revenue } & Change in crop area & 64.6 & 26.4 & 32.6 \\
\hline & Change in crop yield & 41.5 & 16.3 & 43.0 \\
\hline & Change in crop price & 6.1 & 53.3 & 25.8 \\
\hline \multirow[t]{4}{*}{ Total cereal revenue } & Change in crop total cereal area & 60.6 & 28.0 & 41.7 \\
\hline & Change in crop yield & 19.6 & -1.3 & 30.8 \\
\hline & Change in acreage shares & 3.3 & 0.1 & -0.2 \\
\hline & Change in crop price & 15.3 & 64.0 & 27.5 \\
\hline
\end{tabular}

SOURCE: Authors' computations using Central Statistical Agency data (Ethiopia, CSA, various years).

NOTE: The annual Agricultural Sample Survey for 2002/03 was not implemented. Thus, 2002/03 is not included; that is, the period 2001/02-2004/05 includes 2001/02, 2003/04, and 2004/05.

Finally, we examine changes in total cereal revenue, calculated as the sum of the value of output of the five major cereals covered. As noted earlier, consumer price index-deflated real prices are used in computing the value of crop output. Aggregation across crops leads to a fourth source of revenue growth, namely the share of each crop in total cereal acreage. In other words, change in a specific crop's acreage has two components - change in total acreage and change in its share of total acreage.

The results of the decomposition exercise for total cereals are reported in Table 3.11 (bottom four rows for periods 1998/99-2000/01, 2001/02-2004/05, and 2005/06-2007/08) and Table 3.12.

Consistent with previous results, change in total cereal acreage was a primary source of growth in total cereal revenue. That price changes were a competing source in this case is an interesting variation. Change in allocation of cereal acreage was rather limited and thus contributed very little to revenue 


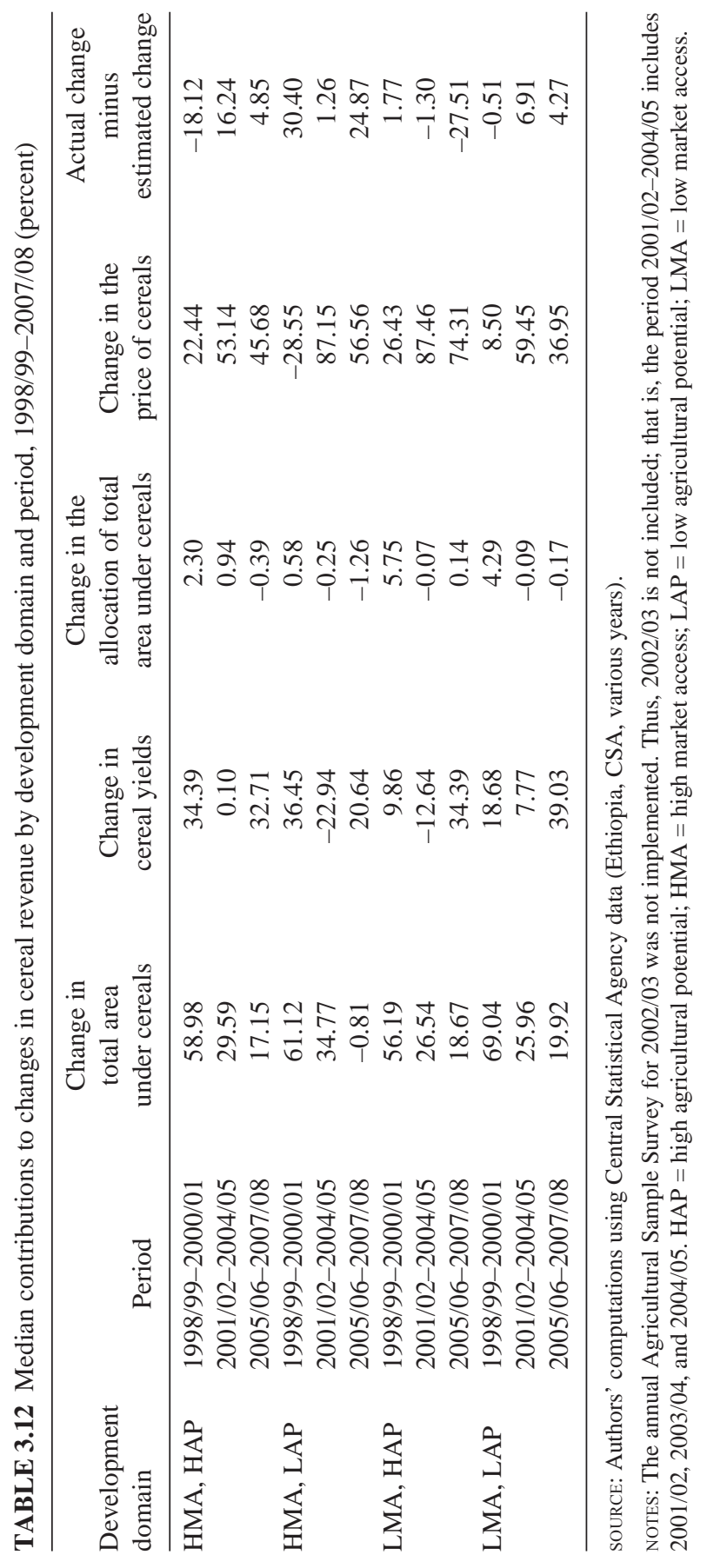


expansion. Its role is likely to be more prominent when a more inclusive set of crops is considered (if pulses and oilseeds are added, for example).

As before, a statistically significant difference in the pattern of contributions to revenue growth could not be ascertained across development domains. The opposite is true across time periods, however (see Tables 3.11 and 3.12). A clear dominance of acreage expansions is found for the first period (1998/99$2000 / 01$ ), while a considerable rise in the contribution of price changes is found for 2001/02-2004/05. In a reversal of outcomes, changes in yield were positive and considerable, though second to price changes, as a source of revenue growth in the last period (2005/06-2007/08).

\section{Other Crop Agriculture}

Although the production of cereals is by far the most important sector in Ethiopian agriculture, it is also important to discuss the other crops given that the area cultivated with these crops is increasing more rapidly than cereal area. The other main crops discussed here are pulses, oilseeds, coffee, and enset. Table 3.13 presents the area cultivated in these crops in the periods 1994/95-2000/01 and 2003/04-2008/09, also giving the acreage growth rates within each of these two periods. ${ }^{6}$

\section{Pulses}

In the periods 1994/95-2000/01 and 2003/04-2008/09, pulse area was 12.0 percent and 12.4 percent of the total area cultivated, respectively. Annual production averaged 1.5 million tons; this represents 8.5 percent of total yearly production (in the period 2004/05-2007/08; see Table 3.1). The share of the area cultivated in pulses is increasing, since pulse area is increasing faster than total area cultivated with cereals. In the period 2003/04-2008/09, this was 6.6 percent per year, which was faster than the yearly growth in cereals ( 4.6 percent). The main pulses are horse beans (Vicia faba var. minor), field peas (Pisum arvense), haricot beans (Phaseolus vulgaris), and chickpeas (Cicer arietinum). They form an important basis for nonmeat national dishes and are principal protein sources.

\section{Oilseeds}

The main oilseeds are neug (Guizotia abyssinica, also known as noug or niger seed), linseed (Linum usitatissimum, also known as flax), and sesame (Sesamum indicum), with sesame increasing in importance over time. The cultivation of neug is found mostly in the northern and central highlands at elevations between 1,800 and 2,500 meters. Linseed is cultivated in the same areas as niger seed. Sesame grows at elevations from sea level to about 1,500 meters. Oilseeds are the third major crop category according to acreage: 5.4 percent and 6.8 percent

6. Note that no data at the administrative zone levels are available for either 2001/02 or 2002/03. 
TABLE 3.13 Area cultivated, share of all crops, and growth rate (smallholders, meher season), 1994/95-2008/09

\begin{tabular}{|c|c|c|c|c|c|c|}
\hline \multirow[b]{2}{*}{ Crop } & \multicolumn{3}{|c|}{ 1994/95-2000/01 } & \multicolumn{3}{|c|}{ 2003/04-2008/09 } \\
\hline & $\begin{array}{c}\text { Area } \\
\text { (thousands } \\
\text { of hectares) }\end{array}$ & $\begin{array}{c}\text { Share } \\
\text { of area } \\
\text { (percent) }\end{array}$ & $\begin{array}{c}\text { Area } \\
\text { growth } \\
\text { (percent) }\end{array}$ & $\begin{array}{l}\text { Area } \\
\text { (thousands } \\
\text { of hectares) }\end{array}$ & $\begin{array}{c}\text { Share } \\
\text { of area } \\
\text { (percent) }\end{array}$ & $\begin{array}{c}\text { Area } \\
\text { growth } \\
\text { (percent) }\end{array}$ \\
\hline Cereals & 6,545 & 82.6 & 3.2 & 8,115 & 73.5 & 4.6 \\
\hline Pulses & 954 & 12.0 & 4.7 & 1,370 & 12.4 & 6.6 \\
\hline Horse beans & 336 & 4.2 & 2.4 & 470 & 4.2 & 6.1 \\
\hline Field peas & 159 & 2.0 & 1.4 & 227 & 2.1 & -0.5 \\
\hline Haricot beans & 122 & 1.5 & 15.9 & 219 & 2.0 & 5.9 \\
\hline Chickpeas & 172 & 2.2 & 4.3 & 197 & 1.8 & 8.9 \\
\hline Other & 165 & 2.1 & 5.9 & 257 & 2.3 & 13.7 \\
\hline Oilseeds & 426 & 5.4 & 5.6 & 749 & 6.8 & 4.3 \\
\hline Neug & 240 & 3.0 & 6.4 & 303 & 2.8 & -0.8 \\
\hline Linseed & 115 & 1.5 & -3.0 & 186 & 1.7 & -1.5 \\
\hline Sesame & 23 & 0.3 & $33.1^{\mathrm{a}}$ & 185 & 1.6 & 20.5 \\
\hline Other & 48 & 0.6 & 7.8 & 75 & 0.7 & 7.2 \\
\hline Subtotal & 7,926 & 100.0 & 3.5 & 10,235 & 92.7 & 4.8 \\
\hline Vegetables & n.a. & n.a. & n.a. & 112 & 1.0 & 11.7 \\
\hline Root crops & n.a. & n.a. & n.a. & 167 & 1.5 & 0.5 \\
\hline Fruit crops & n.a. & n.a. & n.a. & 49 & 0.4 & 4.1 \\
\hline Cash crops & n.a. & n.a. & n.a. & 485 & 4.4 & 9.8 \\
\hline Chat & n.a. & n.a. & n.a. & 136 & 1.2 & 6.1 \\
\hline Coffee & n.a. & n.a. & n.a. & 308 & 2.8 & 12.3 \\
\hline Hops & n.a. & n.a. & n.a. & 23 & 0.2 & 3.7 \\
\hline Sugarcane & n.a. & n.a. & n.a. & 18 & 0.2 & 2.3 \\
\hline Total $^{\mathrm{b}}$ & 7,926 & 100.0 & 100.0 & 11,048 & 100.0 & 5.1 \\
\hline
\end{tabular}

SOURCE: Central Statistical Agency production data (Ethiopia, CSA, various years).

NOTE: n.a. $=$ not available.

aThe sesame growth rate is for 1995/96-2000/01.

boes not include enset (279,000 hectares in 2008/09). Data on vegetables, root crops, fruit crops, and cash crops were not available for 1994/95-2000/01. Thus, the total for 1994/95-2000/01 is not comparable to the total for 2003/04-2008/09.

of the total area cultivated was occupied by oilseeds in the periods 1994/952000/01 and 2003/04-2008/09, respectively (see Table 3.13). The area's growth rate was 5.6 percent per year in the first period, though it declined to 4.3 percent per year in the second period. This slower growth was mainly due to negative yearly growth rates in the neug and linseed areas. These were balanced by fast growth in the sesame area. Sesame grew from essentially zero in 1994/95 to 288,000 hectares in 2008/09, with an impressive growth rate of 33.1 percent per year in the first half of that period and a growth rate of 20.5 percent per year in 2003/04-2008/09. 
In 2007/08, a total of 760,000 tons of oilseeds were produced; this was 3 percent of total annual production. Smallholder farms produced 81.3 percent of total oilseed production, while large farms produced 18.7 percent. However, large farms produced 42.6 percent of total sesame output. Sesame seed has the highest value per ton of Ethiopian oilseeds, more than twice the value of linseed. ${ }^{7}$ According to market value, oilseeds are much more important than pulses.

\section{Coffee}

In 2003/04-2008/09, coffee was cultivated by 3 million farmers on a total of 308,000 ha, which was only 2.8 percent of the total cultivated area. However, the share of the area cultivated in coffee increased by 12.3 percent per year from $2003 / 04$ to 2008/09. In 2008/09, 337,000 tons were produced, 1.3 percent of the total production; 19 percent of the total coffee output was produced by large farms. Coffee is Ethiopia's major export product, and Ethiopia is the world's fifth-largest producer of coffee.

\section{Enset}

Enset (Ensete ventricosum) is commonly known as "false banana" for its close resemblance to the domesticated banana plant, but its fruit is not edible. Enset grows best at altitudes higher than 1,600 meters above sea level, not because it cannot withstand heat but because it needs adequate soil moisture. It can survive seasonal rainfall shortages but succumbs to prolonged droughts. ${ }^{8}$

In 2008/09, enset was cultivated on 279,000 hectares, 2.5 percent of the total cultivated area. As many as 7 million people consume carbohydrate-rich, low-protein enset roots as a staple or co-staple food. For many households it forms an important food security reserve against failures of other crops. Besides being used as a staple food, enset is also used for animal fodder, fiber production, and construction materials and for its medicinal value.

\section{Other Crops}

Only 1 percent of the total area cultivated, the equivalent of 112,000 hectares, is used to grow vegetables. However, the importance of vegetables is growing; there was 11.7 percent per year growth in acreage from 2003/04 to 2008/09 (see Table 3.13). This increase in growth rate is comparable to that of coffee (12.3 percent). Vegetables, together with sesame and coffee, are the crops with the largest acreage increases in recent years.

7. Ethiopia is the fifth-largest world producer of linseed and the sixth-largest producer of sesame seed; it is the third-largest world exporter of sesame seed and an important exporter of neug (niger seed).

8. Each plant takes four to seven years to mature. The plant is cut before flowering, and the pseudostem (stalk or base) and leaf midribs are scraped to collect the pulpy white juice. The pulp is then fermented for 10-25 days in the soil, followed by another 20 days of sun drying. Finally, enset-based food, in the form of a steam-baked flatbread or a kind of porridge, can be prepared. 
Chat is an important cash crop, and its significance is increasing. Only 1.2 percent of the total area cultivated is used for chat production; however, the area cultivated is increasing rapidly - by 6.1 percent per year in 2003/042008/09 (see Table 3.13).

\section{Constraints and Opportunities in Crop Agriculture}

Much of the increase in crop production in the past decade has been due to increases in area cultivated. To what extent the area cultivated can continue to expand remains an important question. It is probable that in the highland areas, expansion of cultivated area will have to come almost exclusively from reduction in pastureland. In most instances, this land is likely to be less fertile than existing cropland. Increased use of intercropping or double cropping may allow some expansion of the area cultivated as well. Expansion of the area cultivated outside of the highland regions will require major investments in infrastructure and might involve reductions in forest areas, with important negative environmental implications. As a consequence, it seems that obtaining higher yield rates is the challenge of Ethiopia's agricultural system.

Numerous constraints to yield and productivity growth have been identified, including relatively low levels of use of inputs (fertilizer, pesticide, improved seeds), low levels of irrigation, soil degradation and soil erosion, inadequate agricultural research and extension, and constraints to market development.

The limited use of modern inputs is a major characteristic of crop production in Ethiopia, and it seems to be a major explanation for its current low productivity. Table 3.14 shows that in 2007/08 only about 40 percent of cereal acreage benefited from chemical fertilizers, with the highest level of application in wheat areas. It is remarkable that the share of fertilizer-applied area in cereal cultivation declined from 2001/02 to 2007/08 after an increase in 2001/02 compared to 1997/98. The opposite is seen when the amount of fertilizer used per hectare of fertilizer-applied cereal area is considered. In that case, the levels used in 2001/02 were lower than in 1997/98, but an increase was noted in $2007 / 08$ compared to 2001/02. In general, the intensity of fertilizer use is relatively low when estimated as the quantity of fertilizer per hectare of total cereal acreage. However, it is broadly comparable to the intensity in Asia when measured as the quantity of fertilizer per hectare of fertilizer-applied cereal area (Agwe, Morris, and Fernandez 2007).

Though increasing, the use of other modern inputs is even more limited (Table 3.15). In 2007/08, improved seeds were applied over about 5 percent of cereal acreage. ${ }^{9}$ The highest rate was in maize production (19.5 percent), with negligible rates in the production of other cereals. Improved irrigation techniques are even less applied. Only 1 percent of cereal acreage was irrigated in

9. Note that the estimate of the use of improved seeds is substantially higher if replanting of improved seed from own production is included (see Chapter 4). 

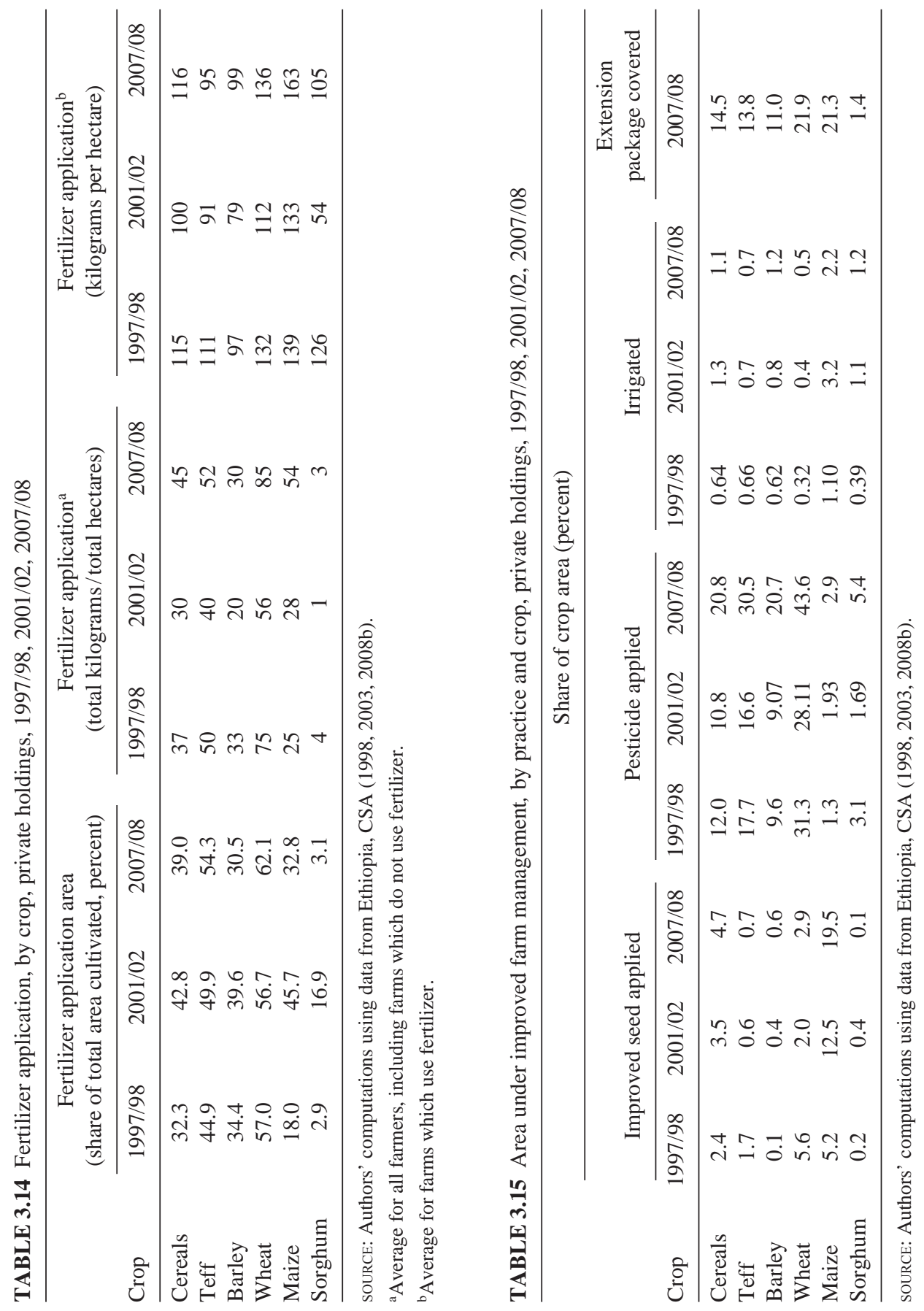
2007/08. Pesticides were applied to 20.8 percent of the total cereal acreage in 2007/08. Furthermore, the use of improved seeds, pesticides, and irrigation has been increasing only slowly in the past decade. The constraints related to cereal production are similar to the ones associated with crop production more broadly.

Several policy initiatives have been taken to stimulate productivity. In the 1990s, the Ethiopian government tried to improve Ethiopian agriculture through a range of measures. In 1993 Sasakawa Global 2000 (SG2000), an international nongovernmental organization for assisting small-scale farmers in SubSaharan African countries to increase staple foodcrop production, began work in Ethiopia in partnership with the government. ${ }^{10}$ In 1994/1995 the government introduced PADETES (the Participatory Demonstration and Training Extension System) with SG2000 principles as a model. ${ }^{11}$

However, there are concerns that these state-led cereal intensification programs are not consistently generating the desired effects (Spielman 2008). For example, distribution of improved maize seeds is a main focus, but adoption of improved seeds has generally been disappointing. Shortfalls in supply, decreasing seed quality, and delayed deliveries may explain this. Similarly, there is evidence suggesting that many farmers have stopped using seed and fertilizer inputs over time due to poor extension service, cost, the unavailability of preferred varieties and other inputs from suppliers, a preference for local varieties, or other such factors (Bonger, Ayele, and Kumsa 2004; EEA/EEPRI 2006; Spielman 2008).

To illustrate the international position of Ethiopia and to indicate its potential for growth, Table 3.16 presents the cereal yields of different countries in eastern Africa for the period 2006-08. FAOSTAT (FAO Statistical Database) data (FAO various years) show that Ethiopia has cereal yields similar to those of Uganda; Kenya and Malawi have higher cereal yields; and Rwanda, Sudan, and Tanzania have much lower yields. Although Ethiopia achieves a higher cereal yield than the average for eastern Africa, it has a lower yield than the average for the least developed countries. Looking in more detail at individual

10. SG2000 advocated high-external-input technologies. The program provided credit, inputs (fertilizer and improved maize seeds), and extension assistance to participants willing to establish half-hectare demonstration plots on their own land. Data from the SG2000 demonstration plots revealed that the use of improved seeds and fertilizer is strongly associated with higher yields, but medium input levels were as profitable as or more profitable than high input levels. Other factors affecting yields were soil type, frequency of plowing, planting time, plant spacing, and weeding (Howard et al. 2003). However, the authors found no evidence of a successful expansion of the pilot program. Two factors playing a plausible role were these: (1) scaling up took the program into areas with less favorable production and/or market conditions and (2) scaling up required local organizations to take over from the special authorities.

11. PADETES reached about 40 percent of the smallholder farms over a 10 -year period. Initially, the program generated positive impacts in Ethiopia. 
TABLE 3.16 Cereal yield, by country and year, 2006-08

\begin{tabular}{lrrrrr}
\hline & \multicolumn{3}{c}{ Cereal yield (kilograms per hectare) } & & $\begin{array}{c}\text { Average as a } \\
\text { percentage of } \\
\text { Ethiopia's average } \\
\text { Country }\end{array}$ \\
\cline { 2 - 4 } yield (percent)
\end{tabular}

SOURCE: FAO (various years).

crops (Table 3.17), we find that Ethiopia, compared to the other countries in the region, has higher yields for maize and sorghum but lower yields for wheat.

\section{Conclusions}

Ethiopia's crop agriculture continues to be dominated by the country's numerous small farms, which cultivate mainly cereals for both their own consumption and sales: smallholders account for 96 percent of the total area cultivated. The five major cereals (teff, wheat, maize, sorghum, and barley) occupy almost three-fourths of the total area cultivated and represent almost 70 percent of the total value-added in recent years. Moreover, the cereal acreage is still increasing, though not as fast as the area planted to other crops such as sesame, coffee, chat, vegetables, and pulses.

During the 1990s, most of the increase in cereal production came from increases in area. However, in the 2000s area and yield increases each accounted for about half of production growth, and we thus see an initial start of increasing intensification. Although growth in the area cultivated reached close to 6 percent in the 1990s, with insignificant yield increases, in the 2000s growth in area decreased to approximately 3 percent, with yield growth reaching 3.5 percent. With little suitable land available for the expansion of crop cultivation, especially in the highlands, future cereal production growth will need to come increasingly from yield improvements. The current use of improved inputs is relatively low, suggesting that there is substantial scope for raising productivity through the increasing adoption of improved seeds and both chemical and 


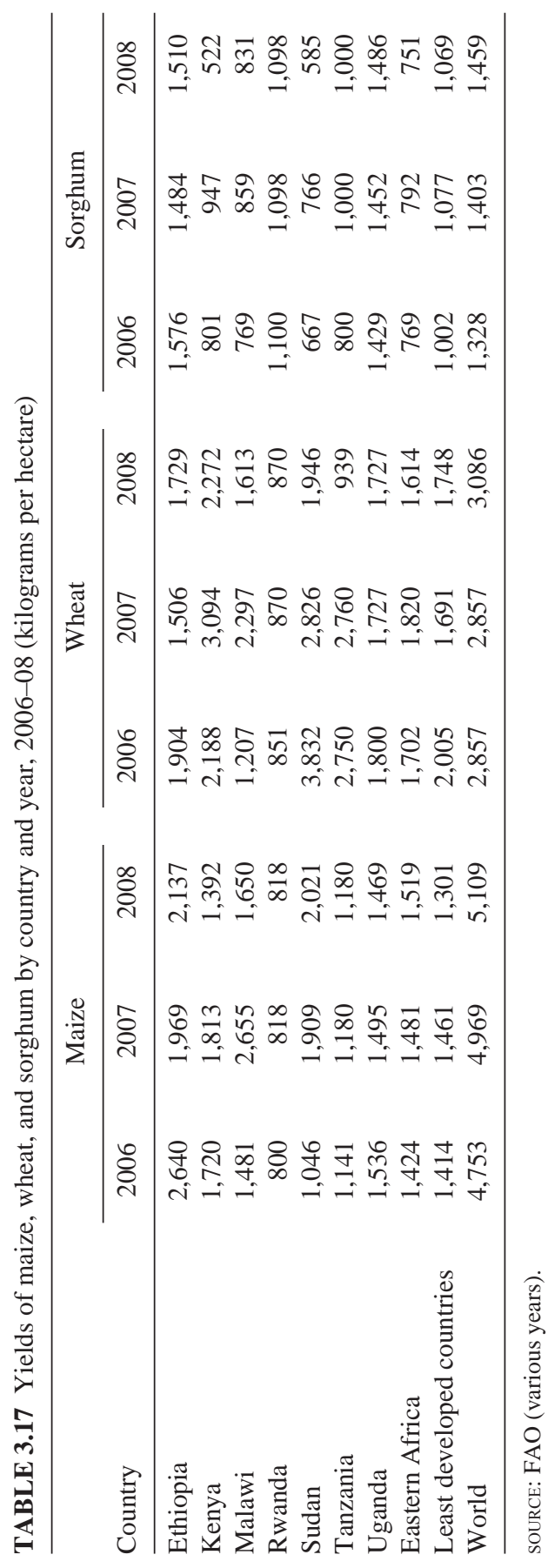


organic fertilizers, at least in the rainfall-sufficient ecologies (and on irrigated farms). However, it appears that growth in real agricultural incomes will also require more diversification and a shift to higher-value crops to respond to changing consumption baskets driven by the increasing per capita income in the country.

\section{References}

Agwe, J., M. Morris, and E. Fernandez. 2007. Africa's Growing Fertilizer Crisis: What Role for Fertilizer? Agricultural and Rural Development Note 21. Washington, DC: World Bank.

Asrat, S., G. Getachew, and A. S. Taffesse. 2010. Trends and Determinants of Cereal Productivity: Econometric Analysis of Nationally Representative Data. ESSP2 Discussion Paper 12. Addis Ababa, Ethiopia: International Food Policy Research Institute.

Bonger, T., G. Ayele, and T. Kumsa. 2004. Agricultural Extension, Adoption, and Diffusion in Ethiopia. Research Report 1. Addis Ababa, Ethiopia: Ethiopian Development Research Institute.

Cotula, L., S. Vermeulen, R. Leonard, and J. Keeley. 2009. Land Grab or Development Opportunity? Agricultural Investment and International Land Deals in Africa. London and Rome: International Institute for Environment and Development, Food and Agriculture Organization, and International Fund for Agricultural Development.

Devereux, S. 2000. Food Insecurity in Ethiopia. Discussion paper for the Department for International Development. Sussex, UK: Institute of Development Studies.

EEA/EEPRI (Ethiopian Economic Association/Ethiopian Economic Policy Research Institute). 2006. Evaluation of the Ethiopian Agricultural Extension with Particular Emphasis on the Participatory Demonstration and Training Extension System (PADETES). Addis Ababa, Ethiopia.

Ethiopia, CSA (Central Statistical Agency). Various years. Crop production data. Addis Ababa.

- 1998. Ethiopian Agricultural Sample Survey (1997/98 [1990 E.C.]): Report on Farm Management Practices (Private Peasant Holdings, Meher Season). Statistical Bulletin 193. Addis Ababa.

- 2003. Ethiopian Agricultural Sample Enumeration (2001/02 [1994 E.C.]): Results at the Country Level, Part II: Report on Farm Management Practices, Livestock and Farm Implements. Addis Ababa.

- 2006. Ethiopian Agricultural Sample Survey (2005/06 [1998 E.C.]). Vol. 1: Report on Area and Production of Crops (Private Peasant Holdings, Meher Season). Statistical Bulletin 361. Addis Ababa.

. 2007. Household Income, Consumption, and Expenditure (HICE) Survey, 2004/5. Vol. 1: Analytical Report. Statistical Bulletin 394. Addis Ababa.

- 2008a. Ethiopian Agricultural Sample Survey (2007/08 [2000 E.C.]). Vol. 5: Report on Area and Production of Belg Season Crops for Private Peasant Holdings. Statistical Bulletin 417. Addis Ababa.

—.2008b. Agricultural Sample Survey (2007/2008 [2000 E.C.]). Vol. 1: Report on 
Area and Production of Crops (Private Peasant Holdings, Meher Season). Statistical Bulletin 417. Addis Ababa.

- 2009. Large and Medium Scale Commercial Farms Sample Survey (2007/2008 [2000 E.C.]): Results at Country and Regional Levels; Report on Area and Production of Crops, and Farm Management Practices. Statistical Bulletin 443. Addis Ababa.

FAO (Food and Agriculture Organization of the United Nations). Various years. Food Production and Food Balance Sheet Databases. Accessed April 2010. http://faostat.fao.org/.

Hamza, M. A., and W. K. Anderson. 2005. "Soil Compaction in Cropping Systems: A Review of the Nature, Causes, and Possible Solutions." Soil and Tillage Research 82 (2): 121-145.

Howard, J., E. Crawford, V. Kelly, M. Demeke, and J. J. Jeje. 2003. "Promoting HighInput Maize Technologies in Africa: The Sasakawa-Global 2000 Experience in Ethiopia and Mozambique." Food Policy 28 (4): 335-348.

Kloos, H., and B. Lindtjorn. 1993. "Famine and Malnutrition." In The Ecology of Health and Disease in Ethiopia, ed. H. Kloos and Z. A. Zein. San Francisco and Oxford, UK: Westview.

McCann, J. C. 1995. People of the Plow: An Agricultural History of Ethiopia, 1800 1990. Madison, WI, US: University of Wisconsin Press.

Spielman, D. J. 2008. Encouraging Economic Growth in Ethiopia: Perspectives on Agricultural Input Markets, Agricultural Extension and Advisory Services, and Agricultural Education and Training. Briefing note. Washington, DC: International Food Policy Research Institute.

Taddesse, G. 2001. "Land Degradation: A Challenge to Ethiopia." Environmental Management 27 (6): 815-824.

Taffesse, A. S. 2009. "Cereal Production in Ethiopia: Recent Trends and Sources of Growth.” International Food Policy Research Institute, Washington, DC. Mimeo. 